\title{
Back Massage and Self-Talk Therapy on Anxiety and Breastfeeding Self-Efficacy in Postpartum Mother: Analytic Descriptive
}

\author{
Cristinawati B/R Haloho*, Leny Latifah, Sri Endang Pujiastuti \\ Poltekkes Kemenkes Semarang, Indonesia \\ *cristinasihaloho68@gmail.com
}

\begin{abstract}
The delivery of the placenta makes the steroid and oxytocin hormone in the mother's body unbalanced then increases the cortisol hormone which influences the recovery and breastfeeding process. Prevalences of anxiety in the postpartum period reach to $15-40 \%$ in some countries. This study explains the effect of the combination of back massage and selftalk therapies on anxiety and breastfeeding self-efficacy which these therapies are psychology therapy and physically combined. This was qualitative research with the massage group only as the control group was conducted in 4 public health centers in Purwodadi, Central of Java. Self-talk was given used cards as a media, Breastfeeding SelfEfficacy (BSES) and The Postpartum Specific Anxiety Scale (PSAS) used as instruments. The result showed that the cards were accepted by respondents as good media to improve their belief in breastfeeding and to improve their love for the babies. The combination of back massage and self-talk reduced their anxiety and increased their belief to breastfeed rather than given back massage only in the control group, that because back massage therapy recovers their bodies and self-talk therapy recovers their psychology given their mind power to enjoy their postpartum period. This combination therapy effective to decrease anxiety and to increase breastfeeding self-efficacy.
\end{abstract}

Keywords: Anxiety, Breastfeeding Self-efficacy, Back Massage, Self-talk 


\section{STRADA Jurnal Ilmiah Kesehatan}

DOI: $10.30994 /$ sjik.v9i2.527

ISSN: 2252-3847 (print); 2614-350X (online)

Vol.9 No.2 November 2020 Page.1747-1754

\section{BACKGROUND}

The delivery of the placenta in the postpartum period influences the hormones suddenly especially the oxytocin and steroid hormone, those are happiness hormone in our body which control the mother emotion. Unbalancing of the hormones affects our brain then makes the mothers over sensitive and changing mood easier ${ }^{1-3}$. The other such as physical, identity, and social changes contribute to increasing anxiety ${ }^{4-5}$ when the anxiety level higher our brain automatically produces the cortisol hormone then inhibits the prolactin and oxytocin hormone which makes recovery and breastfeeding process distrubed ${ }^{6-7}$. The previous study showed that the combination of back massage and self-talk therapy reduces anxiety and increases breastfeeding self-efficacy significantly ${ }^{8}$. In this study, the researcher wants to explain how this combination therapy affects the mother with a deep interview.

\section{METHOD}

\section{A. Study Design}

This study was qualitative research with 2 groups divided by the experimental group which was given the combination of back massage and self-talk therapy and the control group which was given the massage therapy only. Both groups were given therapy 2 times a week for 30 minutes. This study used the interview as primary data after inventory by the researcher then the narrative presented. The researcher interviewed the respondents with some questions about the given therapies and the media used in this study. The purpose of the interview is to get the conclusion of this therapy and actual results about the effectiveness of the combination of back massage and self-talk in reducing anxiety and increasing breastfeeding self-efficacy

B. Populasi dan Sampel

The sample used normal postpartum mothers on the first day after delivery, primipara, and multipara, range of 20 until 30 years old, suffered mild and moderate anxiety. There were 11 mothers in the experimental group and 7 mothers in the control group.

C. Media

This study used love maternal cards as a helping media which was conducted by the researcher for helping the mothers get positive suggestions daily. There were 20 cards with 18 positive suggestions. The cards have most of the suggestions for breastfeeding, the other suggestions for improving their love feeling to their self, their baby and their family, make sure that they can throughout postpartum period happily and more thankful. This media was given to the intervention group as self-talk media, these cards were used at the night and in the morning.

D. Instruments

\section{PSAS}

This is a questioner used for measuring anxiety score which given on the first day before therapy and the last day after therapy. There were 51 points with a Likert scale 1-4 (never until always) in the end it will accumulate then was analyzed by SPSS. Anxiety score divided by 51-70 anxious, 71-90 mild anxiety, 91-111 moderate, and $\geq 112$ depressed. This study used anxious until moderate anxiety.

2. BSES

This is a questioner used for measuring the self-confidence of the mothers in breastfeeding their baby, given on the first day before therapy and on the last day after therapy. There were 14 points with a Likert scale 1-4 (very confident until very not confident) in the end will accumulate then analyzed by SPSS. This questionnaire 


\section{STRADA Jurnal Ilmiah Kesehatan}

DOI: $10.30994 /$ sjik.v9i2.527

ISSN: 2252-3847 (print); 2614-350X (online)

Vol.9 No.2 November 2020 Page.1747-1754

can explain about score per point so the researcher can understand which point has the lowest confidence.

\section{RESULTS}

\section{General Characteristic of Respondents}

General Characteristic of Respondents

Based on Table 1 showed that the mean age in the intervention group was 26 years old with minimum age 22 years old and maximum age 30 years old meanwhile mean in the control group was 25 years with minimum age 27 years old and maximum age 27 years old. Most of the respondents in the intervention group and in the control group were workers and most of them both in the intervention and control group were primiparous.

Table 1 The Respondents Characteristic Distribution Based on Age, Employment Status and Parity of Control Group and Intervention Group

\begin{tabular}{|c|c|c|c|c|}
\hline \multirow{2}{*}{ Charachteristics } & \multicolumn{2}{|c|}{ Intervention } & \multicolumn{2}{|c|}{ Control } \\
\hline & $\mathbf{N}$ & $\%$ & $\mathbf{N}$ & $\%$ \\
\hline \multicolumn{5}{|l|}{ Age } \\
\hline Mean & \multicolumn{2}{|c|}{25.91} & \multicolumn{2}{|c|}{24,71} \\
\hline Min-Max & \multicolumn{2}{|c|}{$22-30$} & \multicolumn{2}{|c|}{$21-27$} \\
\hline Median & \multicolumn{2}{|c|}{26.00} & \multicolumn{2}{|c|}{26.00} \\
\hline \multicolumn{5}{|l|}{ Parity } \\
\hline Primipara & 6 & 54.5 & 4 & 57 \\
\hline Multipara & 5 & 45.5 & 3 & 43 \\
\hline \multicolumn{5}{|l|}{ Employment } \\
\hline Employed & 9 & 81.8 & 5 & 71.4 \\
\hline Unemployed & 2 & 18.2 & 2 & 28.6 \\
\hline
\end{tabular}

\section{Respondents Anxiety Problems}

In this study, the researcher interviewed all of the respondents, there were some questions about the respondent's problems, anxiety, and responsiveness. The respondents who have inclusive characteristics of this study were been the sample.

There were 2 respondents 1 in the intervention group and the other in the control group said that they have no confidence in the breastfeeding process, they thought that they have small breast so they can not give their baby fully breastmilk and want to give formula milk to their baby. They had tried to breastfeed their baby but the milk would not come out. They are primiparous.

"I had tried to breastfeed from the beginning but until now my breast can not give my baby milk, it doesn't come out and I felt tired to try. I think my breast too little that's why it never comes out like my mom, she has the same experience as me and she had given me formula milk and it is okay for me, she asked me to give formula too rather than my baby cry all the night and I have to stay up along day I will give formula then.." (Mrs.Andrea, 24 years old)

"My breast is too little, I had tried to massage but it still wont to come out, I think to give formula then breast milk when it comes out.." (Mrs.Siti, 27 years old)

They are primiparous, Mrs. Andrea is a mother with last management postgraduate education, and Mrs. Siti just senior high school education. Although Mrs. Andrea has high education not mean she has high confidence in the breastfeeding process, she still wants to 


\section{STRADA Jurnal Ilmiah Kesehatan}

DOI: $10.30994 /$ sjik.v9i2.527

ISSN: 2252-3847 (print); 2614-350X (online)

Vol.9 No.2 November 2020 Page.1747-1754

give formula milk to her baby. In Mrs. Andrea's case, family support is more important. She decided to gove formula because her mother asked her to do it.

As long this study in the second meeting, there were 4 respondents who said that another anxious about back to work, feeling mad while breastfeeding, feeling bad for their baby and for their self there were 2 respondents from the control group and 2 respondents from the intervention group. They said that they are worry they can not give breastmilk and can not give their best love to their baby. The other respondents said the same but not too worry about that, just sometimes they feel mad when they are breastfeeding the baby.

"In my first birth I have no job that's why I can take care of my baby fully, but now I am not sure and thought about back to my job. I can not give my baby the best food like this daily, and I feel sorry of it.."(Mrs. Eka, 27 years old)

"This is my first experience to be mother, I still feel hard to control my mood and my emotion, I have felt tired for staying up and my baby can not understand me, I have tried for 3 days but my breastmilk hard to come, it comes just little and my baby crying continuously. It makes me mad at him but I feel sad too, I feel like I am not the best mom for him. I'm confused now what should I do.." (Mrs. Fatima, 21 years old)

"When I was pregnant, I am sure if I can breastfeed my baby, I think that is simple and easy to do but, in fact, I feel hard to do it. I have to stay up with all pain in my body on the second day until now my breastmilk doesn't come out anymore. It comes out when you give me massage only then it doesn't come like the first day.."(Mrs. Laeli, 21 years old)

"I feel hard to give my breastmilk, my parents asked me to give formula because my baby cried all night because my breastmilk not enough to her but I ignored to give formula and want to continue to give my mine and I feel bad to my baby.." (Mrs. Naila, 25 years old)

Mrs. Eka and Mrs. Fatima were the intervention group which is given the love maternal cards, Mrs. Eka said that did not think about back to work as a problem but after reading and got the suggestion, she aware if that is a problem. Mrs. Fatima said that if the cards make her aware of the breastfeeding process is difficult and has to calm down, relax, and have to enjoy it. She said that she is trying to enjoy although she knows it needs time meanwhile Mrs. Laeli and Mrs. Naila they did not get the self-talk so they didn't aware about back to a job or control their emotion is important when breastfeeding process like Mrs. Laeli told about the milk comes out after massage only.

\section{Feedback about The Procedure of This Study}

In the first step of this study was given an explanation for my enumerators. There were 2 enumerators who have a massage certificate and a bachelor of midwifery. The enumerators used a guidebook including the procedure of massage and the self-talk. Each enumerator guide 2 public health center. In this step, the researcher explained how to filter the respondent's used inclusive characteristics, how to use the guide book and the cards, and how to evaluate. All of the respondent's responses to the treatments and procedure were recorded by phone.

" The guideline book is good, there are detail points and it is clear. This book easy to understand and easy to use because there is a picture so it helps much.." (Mrs. Umi, 25 years old)

"The guideline book gives me more information about how this combination therapy works, and I feel want to try this at home because I have a baby too she is 9 months"(Mrs. Uli, 24 years old)

All of the respondents said that enjoy the procedure, easy to understand, and the step is clear with the general language. The time of massage is right for them because they feel better 


\section{STRADA Jurnal Ilmiah Kesehatan}

DOI: $10.30994 /$ sjik.v9i2.527

ISSN: 2252-3847 (print); 2614-350X (online)

Vol.9 No.2 November 2020 Page.1747-1754

after getting the massage. They said that the enumerators were good given massage although some respondents want to be touched more in the other parts of bodies such as the arms. Some respondents said that how if the cards used voice so it can be downloaded by phone so they can hear the suggestions from their phone so they can hear the suggestions too. The researcher got all statements about the procedure on the last day of the therapy.

"I think the cards are good enough, the clour is unique, the picture is cute and the words are worth but I have a lazy habit to read so that is better when it can be sounded.."(Mrs. Ririn 24, years old)

"The procedure of massage is good I feel happy because it is free and I can enjoy it but I think I need more massage in my arms, because I have to breastfeed my baby with one side so my arms sometimes feel pain, I think that will better.."(Mrs. Annisa, 26 years old)

"The massage will better if the arms included.." (Mrs. Imelda, 28 years old)

"The procedure of self-talk makes me aware how important controlling our emotion when we are breastfeeding our baby, because our baby can feel our emotion too.."(Mrs. Fatima, 21 years old)

"The suggestion can understand what that I felt, it can release my emotion and make me aware how to control it.." (Mrs. Eka, 27 years old)

Most of the respondents said that all of the procedures were good meanwhile the cards they said that better if the cards use an app in the app store so they can use it everywhere and anywhere because with cards it can be lost and there are some people can not read or lazy to read so it better if there is sound too.

\section{The Benefit of Therapy Decrise Anxiety and Increase Breastfeeding Self-efficacy}

All of the respondents in both the intervention group and the control group said that the therapy can give them relaxation, release the pain, help the milk production, improve our body in better condition. Based on table 2, we can see there no one feels higher anxious after the therapy the all of SPAS scores are reduced.

"The massage gives me power after the delivery process, I feel enjoy with that massage, the duration is good enough for me and the technique is different with the shaman.." (Mrs. Eka, 27 years old)

"I feel like my breastmilk can come out because of the massage, I have tried to breastfeed my baby the second day after the massage it is harder to come out.."Mrs. Laeli, 22 years old)

"I feel the massage helps me to improve my breastmilk because my old sister can breastfeed her baby fully after a week but I did before a week thankyou.."(Mrs. Delisa, 26 years old)

Table 2. Reducing Anxious in The Intervention and Control Groups Before and After Therapy

\begin{tabular}{|c|c|c|}
\hline \multirow{2}{*}{ Patient } & \multicolumn{2}{|c|}{ Score PSAS } \\
\cline { 2 - 3 } & Pre & Post \\
\hline EK 1 & 93 & 68 \\
\hline EK 2 & 99 & 66 \\
\hline EK 3 & 91 & 67 \\
\hline EK 4 & 91 & 64 \\
\hline EK 5 & 91 & 70 \\
\hline EK 6 & 90 & 67 \\
\hline EK 7 & 99 & 74 \\
\hline
\end{tabular}

\begin{tabular}{|c|c|c|}
\hline \multirow{2}{*}{ Patient } & \multicolumn{2}{|c|}{ Score PSAS } \\
\cline { 2 - 3 } & Pre & Post \\
\hline $\mathrm{K} 1$ & 93 & 72 \\
\hline $\mathrm{K} 2$ & 93 & 79 \\
\hline $\mathrm{K} 3$ & 93 & 82 \\
\hline $\mathrm{K} 4$ & 91 & 89 \\
\hline $\mathrm{K} 5$ & 95 & 86 \\
\hline $\mathrm{K} 6$ & 91 & 81 \\
\hline $\mathrm{K} 7$ & 93 & 90 \\
\hline
\end{tabular}




\section{STRADA Jurnal Ilmiah Kesehatan}

DOI: $10.30994 /$ sjik.v9i2.527

ISSN: 2252-3847 (print); 2614-350X (online)

Vol.9 No.2 November 2020 Page.1747-1754

\begin{tabular}{|c|c|c|}
\hline EK 8 & 92 & 69 \\
\hline EK 9 & 104 & 73 \\
\hline EK 10 & 102 & 77 \\
\hline EK 11 & 96 & 72 \\
\hline
\end{tabular}

Table 3 The anxiety level percentage during pre and post-intervention of the postpartum mothers

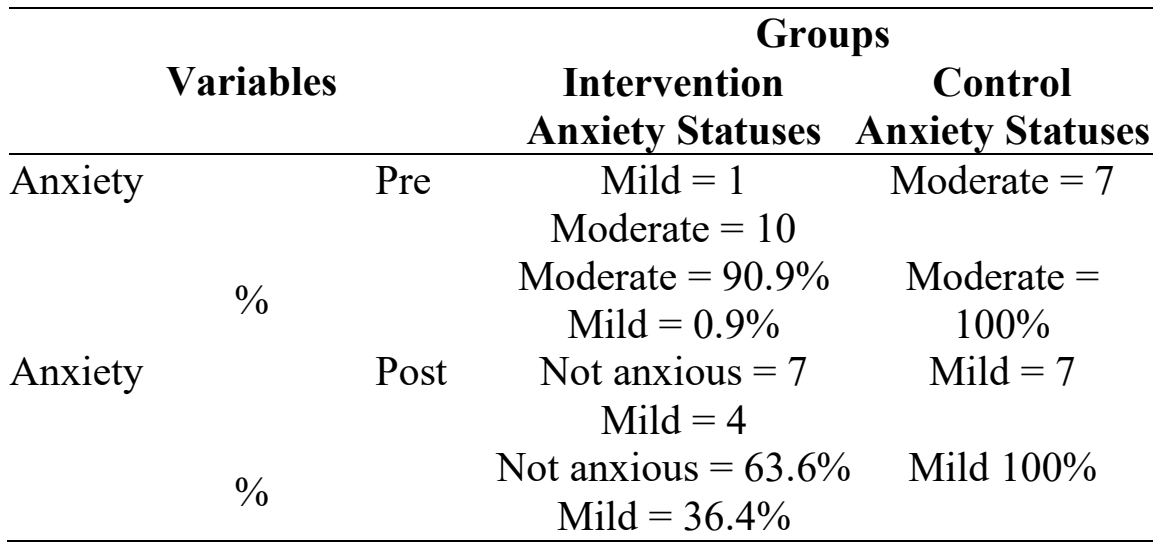

Table 3 showed that the decrease of anxiety in the intervention group bigger than the decrease in the control group. In the control group there still 7 respondents with mild anxiety.

Table 4 The analysis of back massage and self-talk combinations toward breastfeeding self-efficacy of the postpartum mothers

\begin{tabular}{lcccc}
\hline \multicolumn{1}{c}{ Grups } & & N & $\begin{array}{c}\text { Mean } \\
\text { Rank }\end{array}$ & $\begin{array}{c}\text { Sum of } \\
\text { Ranks }\end{array}$ \\
\hline Pre-post test & Negative Ranks & $0^{\mathrm{a}}$ & .00 & .00 \\
Exsperiment & Positive Ranks & $14^{\mathrm{b}}$ & 7.50 & 105.00 \\
& Ties & $0^{\mathrm{c}}$ & & \\
& Total & 14 & & \\
Pre-post test & Negative Ranks & $0^{\mathrm{a}}$ & .00 & .00 \\
Control & Positive Ranks & $11^{\mathrm{b}}$ & 6.00 & 66.00 \\
& Ties & $3^{\mathrm{c}}$ & & \\
\hline
\end{tabular}

The giving self-talk to the intervention group can improve the confident feeling higher than without the self-talk that because the table 3 showed that there are 3 respondents with the same score before and after therapy in the different point. There were respondent still unconfident to breastfeed her baby in front of people, respondent still unconfident breastfeeding need a long time to make the baby full, respondent still unconfident to remember what the last time the baby gets breastmilk and unconfident if the baby feels full 


\section{STRADA Jurnal Ilmiah Kesehatan}

DOI: $10.30994 /$ sjik.v9i2.527

ISSN: 2252-3847 (print); 2614-350X (online)

Vol.9 No.2 November 2020 Page.1747-1754

even breastfeeding different with the intervention group there was no one unconfident anymore.

\section{DISCUSSION}

The result of this study showed how important self-talk is. The combination therapy with self-talk more effect the reducing of anxiety and increasing breastfeeding self-efficacy. It is suited as the old study that said the massage therapy gives comfort feeling and gives relax so that the effect accepted by skin then continued by nerve on the skin to our body until our brain then the brain release the oxytocin hormone then the cortisol can be inhibited 9-13 the effects of massage make adrenaline and nor-adrenaline pressed then enhance our blood circulation and increase our antibody ${ }^{14}$.

Self-talk as a booster of the combination therapy can increase the mother's cognitive with positive suggestions. The suggestions are acceptable to the mother's subconscious then affect the mother to do the suggestions automatically and those give power to the mother's mind to reach happiness like the suggestions said ${ }^{15,16}$. The suggestions give some power to the mothers to always thankful, calm down, relax and aware that the baby needs the mother and love much so they have to control their emotions.

\section{CONCLUSION}

The combination therapy is better and effective to reduce the anxiety and to increase breastfeeding self-efficacy because they are double healing therapy. The postpartum period is not about the physical problem only, but about the psychological problem too, and this combination is suitable for the mother because the massage heals the physic and the selftalk heals the psychology of the mothers.

\section{REFERENCES}

1. Reck, C., Tietz, A., Müller, M., Seibold, K. \& Tronick, E. The impact of maternal anxiety disorder on mother-infant interaction in the postpartum period. PLoS One 13, 1-21 (2018).

2. Radoš, S. N., Tadinac, M. \& Herman, R. Anxiety during pregnancy and postpartum: Course, predictors and comorbidity with postpartum depression. Acta Clin. Croat. 57, 39-51 (2018).

3. Field, T. Postpartum Anxiety Prevalence, Predictors and Effects on Child Development: A Review. J. Psychiatry Psychiatr. Disord. 01, 86-102 (2017).

4. Leahy-Warren, P., McCarthy, G. \& Corcoran, P. Postnatal Depression in First-Time Mothers: Prevalence and Relationships Between Functional and Structural Social Support at 6 and 12 Weeks Postpartum. Arch. Psychiatr. Nurs. (2011). doi:10.1016/j.apnu.2010.08.005

5. Chen, C.-K. et al. Depression and Suicide Risk in Hemodialysis Patients With Chronic Renal Failure. Psychosomatics (2010). doi:10.1176/appi.psy.51.6.528

6. Otsuka, K. et al. Effectiveness of a breastfeeding self-efficacy intervention: Do hospital practices make a difference? Matern. Child Health J. 18, 296-306 (2014).

7. Azmoude, E., Jafarnejade, F. \& Mazlom, S. R. The Predictors for Maternal Self-efficacy in Early Parenthood. J. Midwifery Reprod. Heal. 3, 368-376 (2015).

8. International, T. H. E. \& On, S. Public health department faculty of sports science universitas negeri semarang. (2020).

9. Widiastuti, N. M. R. \& Widiani, N. N. A. Improved breastfeeding with back massage among postnatal mothers. Int. J. Res. Med. Sci. 8, 580 (2020). 


\section{STRADA Jurnal Ilmiah Kesehatan}

DOI: $10.30994 /$ sjik.v9i2.527

ISSN: 2252-3847 (print); 2614-350X (online)

Vol.9 No.2 November 2020 Page.1747-1754

10. Harris, M. \& Richards, K. C. The physiological and psychological effects of slow-stroke back massage and hand massage on relaxation in older people. J. Clin. Nurs. 19, 917926 (2010).

11. Mohammadpourhodki, R., Sargolzaei, M. S. \& Basirinezhad, M. H. Evaluating the effect of massage based on slow stroke back massage on the anxiety of candidates for cataract surgery. Rom. J. Ophthalmol. 63, 146-152 (2019).

12. Hsu, W. C., Guo, S. E. \& Chang, C. H. Back massage intervention for improving health and sleep quality among intensive care unit patients. Nurs. Crit. Care 24, 313-319 (2019).

13. Jalalodini, A., Nourian, M., Saatchi, K., Kavousi, A. \& Ghaljeh, M. The effectiveness of slow-stroke back massage on hospitalization anxiety and physiological parameters in school-age children: A randomized clinical trial study. Iran. Red Crescent Med. J. 18, (2016).

14. Meftahi, N., Bervis, S., Taghizadeh, S. \& Ghafarinejad, F. The Effect of Lying in Prone Position on Blood Pressure and Heart Rate with and without Massage. J. Rehabil. Sci. Res. 1, 40-43 (2014).

15. Hall, R. S. The Effect of Self-Talk as an Anxiety Regulation and Intervention on Coincident Anticipation Timing and Batting Performance in Criket. Stat. F. Theor 53, 1689-1699 (2019).

16. Ghasemi, V., Simbar, M., Banaei, M., Saei, M. \& Naz, G. The Effect of Interventions on Breastfeeding Self-efficacy by Using Bandura's Theory in Iranian Mothers: A Systematic Review. 7, 9939-9954 (2019). 